Sustinere

Journal of Environment and Sustainability

Volume 1 Issue 2 (2017) 118-130

Print ISSN: 2549-1245 Online ISSN: 2549-1253

Website: https://sustinerejes.com E-mail: sustinere.jes@iain-surakarta.ac.id

\title{
RESEARCH PAPER \\ The study of urban drainage system based on spatial structure plan
}

\author{
Rahmat Irawan", Ellina S. Pandebesie, Ipung Fitri Purwanti \\ Department of Environmental Engineering, Sepuluh Nopember Institute of Technology, Indonesia \\ Article history: \\ Received 5 August 2017 | Accepted 20 October 2017 | Available online 01 December 2017
}

\begin{abstract}
The whole planning of urban infrastructure development should refer to the Detailed Spatial Planning that has been developed by the Regional Government. One of them is the drainage system planning which also needs to pay attention to the land use change plan. This change would cause an increase of run-off coefficient as a result of the increasing number of structure-covered land. Based on the land use planning of Spatial Structure Planning 2034, there was an increase in land cover with a total area of 75 hectares. Therefore, it is necessary to evaluate the urban drainage system in order to avoid problems in the future. Flood discharge was calculated using the rational formula applying run-off coefficient according to spatial structure plan. The analysis of the existing drainage system was carried out to find out whether it is still capable of accommodating the discharge according to Spatial Structure Planning 2034. Based on the drainage channel capacity analysis, 30 existing channels have to be repaired. They must be adjusted by widening the channel and increase the number of channels by $3191.36 \mathrm{~m}$. Another effort to reduce the flood is by making 179 absorption wells in residential areas.
\end{abstract}

Keywords: Land use change; Praya; spatial structure plan; urban drainage system.

\section{Introduction}

Population of Praya in 2016 was the highest among other sub-districts in District of Central Lombok (Koordinator Statistik Kecamatan Praya, 2017). Population growth in this area increased approximately 4 percent annually (BPS, 2017b). It influences the number of the residential housing. Increasing population may reduce arable land (Brooks et al., 2013). This may also affect open space lands causing a reduction of agricultural or plantation areas, as well as an increase of enclosed or waterproofed land areas. Rain water cannot seep into those impermeable soils, so that an event of high rainfall intensity could lead to flood and inundation. It needs either surface ditches or tile drains or a combination of both to remove excess water from the land (Freevert et al., 1963).

Some urban and environment observers have revealed that puddles are regarded as one of the consequences of conflict of interests between humans and water. These include 
conflicts between building and water spatial planning, and conflicts between spatial planning and water resource management. To minimize the problems, it is necessary to align spatial planning and urban drainage system planning (Kusumadewi et al., 2012).

Based on the land use planning in 2034, there will be an increase of 75 ha of built land or $30 \%$ of the existing land cover. Therefore, it is necessary to conduct a research that aims to synergize the infrastructure planning and spatial planning in an urban area. It is also necessary to attempt to resolve the problem of inundation by technically reviewing the drainage network system and the application of eco-drainage efforts, as well as analyzing financial aspects.

\section{Literature review}

Conversion of land into settlements increases the discharge run off that affects drainage planning (Betaubun et al., 2012). Drainage is one of basic facilities that are designed as a system to meet the needs of the community. It is an important component in the planning of the city. Drainage can also be interpreted as an effort to control the quality of groundwater in relation to salinity. It does not only concern the drainage of surface water but also ground water (Suripin, 2004). Meanwhile, urban drainage system is a unified system of technical and non-technical infrastructures and means of urban drainage (Hasmar, 2012). The urban drainage system is a major part of city infrastructure, which is necessary for the water cycle within and even beyond an urban area (Fengxiang et al., 2018). The lack of proper functioning of urban drainage can be illustrated as the decline of urban drainage services caused, among other things, by the aging of infrastructure and less precise drainage management.

\subsection{Concept of sustainable drainage}

The concept of sustainable drainage systems is a handling priority that aims to manage surface run off by developing facilities to hold rainwater. Based on its functions, rainwater retaining facilities can be grouped into two, namely the storage and absorption types (Suripin, 2004). The major goals of sustainable drainage systems are to manage storm water runoff, to rid the water of any pollutants and to encourage community involvement (Button et al., 2010). There is a need to increase absorbing areas to resolve flooding in urban areas. One of the most efficient methods to absorb storm water is infiltration well (Jifa et al., 2018). The concept of infiltration well is based on natural water balance as a part of hydrological cycle. It allows water to get in to the well which functions as a temporary storage facilities, as well as to infiltrate to become ground water (Sunjoto, 1994).

Eco drainage concept is defined as an attempt to manage the excess water (rainwater) with a variety of methods, such as collecting water in a tub for direct use and holding the water using artificial or natural spoolers. With the concept of eco drainage, the excess rainwater is not promptly dumped into the rivers. The rainwater can be stored in various locations in the region with various methods, so it can be used as a way to conserve the water.

\subsection{Praya}

The area of study, Praya, is sub urban area in the Central Lombok Region, West Nusa Tenggara Province which is located in Lombok Island. The area of Praya lies between 
116 14' 51.17" E; $8^{\circ} 41^{\prime} 11.234^{\prime \prime} \mathrm{S}$ and $116^{\circ} 15^{\prime} 33.022^{\prime \prime}$ E; $8^{\circ} 45^{\prime} 38.075^{\prime \prime}$ S. Total area under the study was $20.8 \mathrm{~km}^{2}$. Location of study is presented in Figure 1. Meanwhile, the existing map of Praya is presented in Figure 2, whilst the spatial planning of Praya for 2034 is revealed in Figure 3.

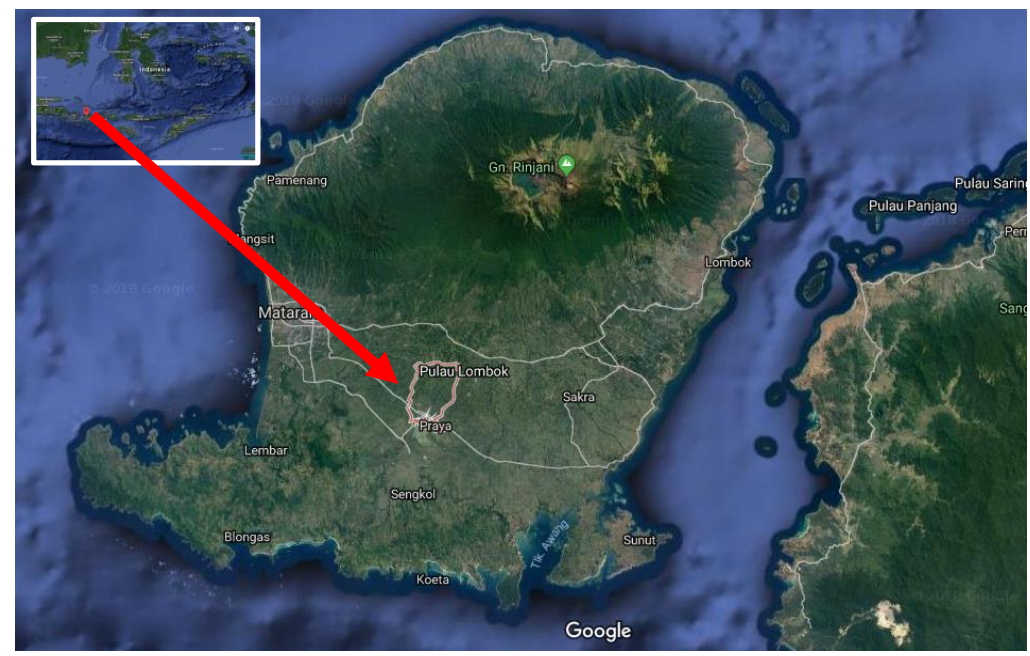

Figure 1. Location of study

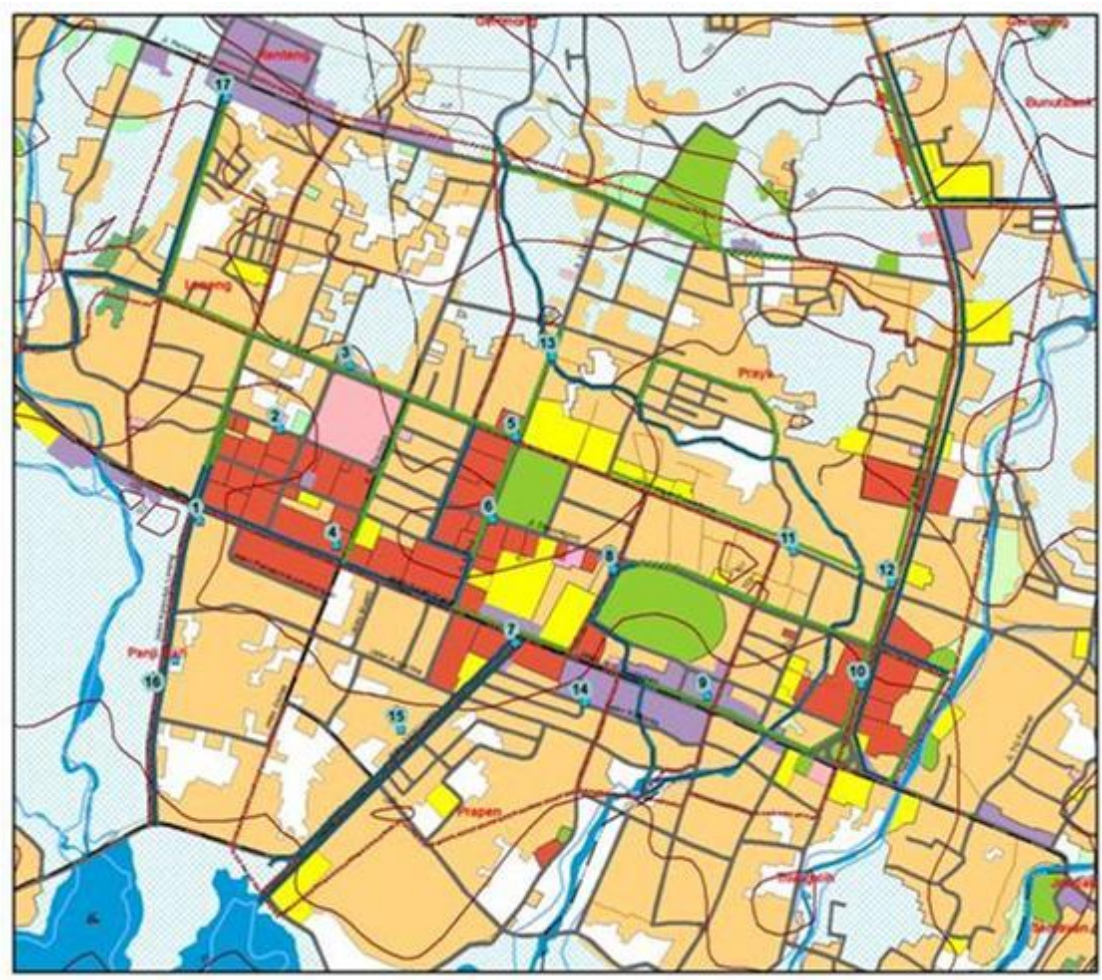

Industry

Garden

Health

Unused land

Road

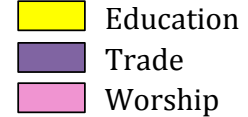

Worship

primary channel

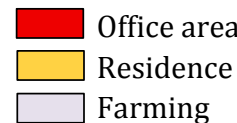

Secondary channel
Green space

R Rice field

Terminal

I--JVillage lane

Figure 2. Map of existing land use 


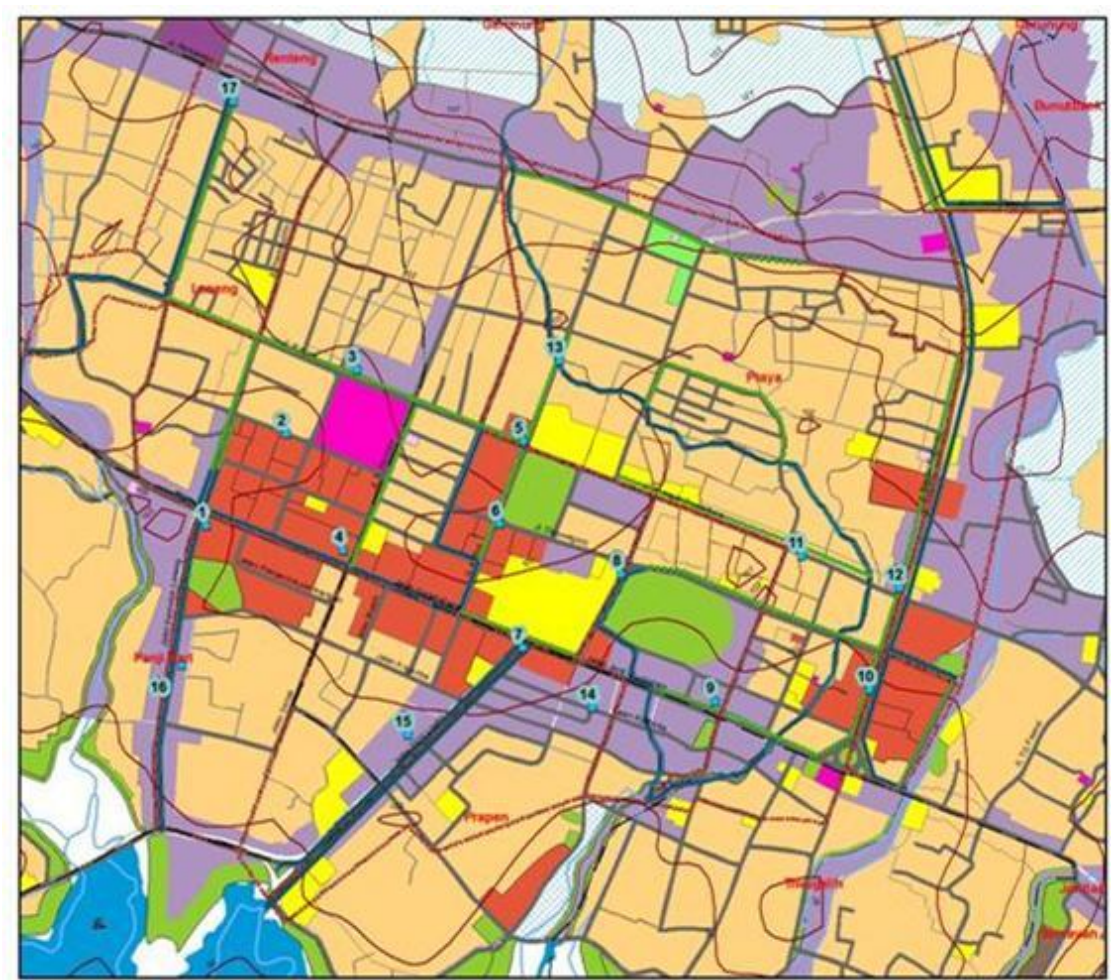

Industry

Garden

Health

Unused land

Road
Office area

Residence

Trade

Worship

primary channel
Farming

Secondary channel
Green space

Rice field

Terminal

Figure 3. Map of the change of land use planning in 2034

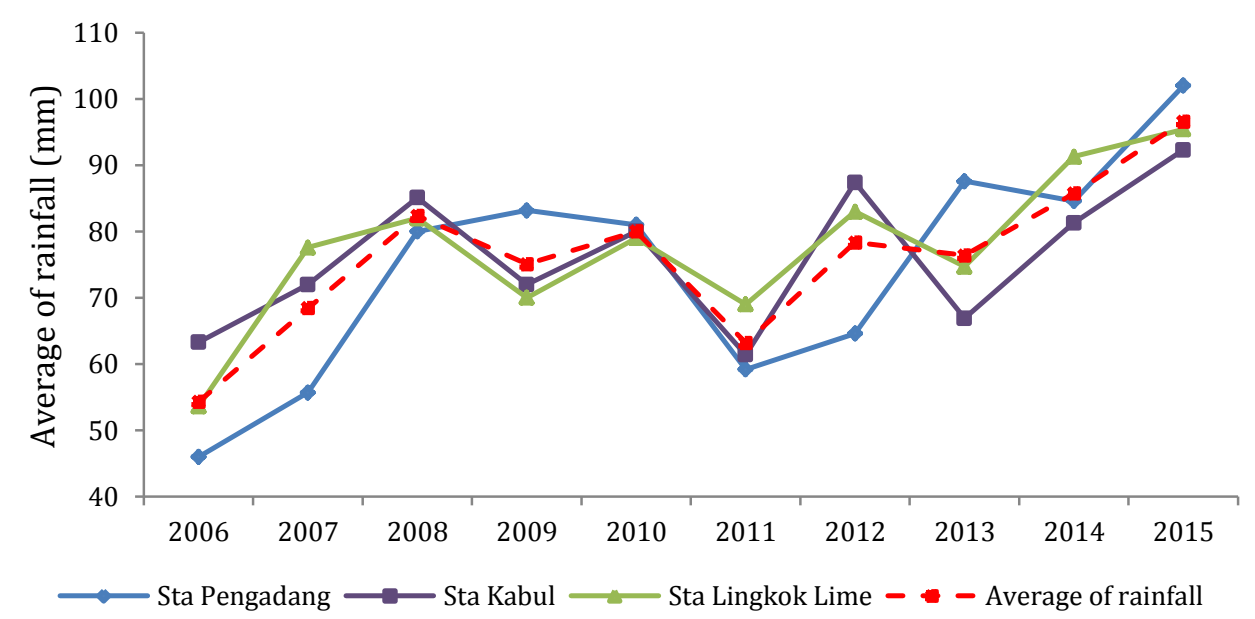

Figure 4. Analysis of average rainfall at three observation stations using Algebraic Method 
Praya climate is tropical rainforest. It was reported that the average of rainy day in 2016 was 17 days/month with average of rainfall was $193 \mathrm{~mm} /$ months (BPS, 2017a). The average rainfalls during 2006 to 2015 are revealed in Figure 4.

The detail of existing land use of Praya is presented in Table 1. The data shows that about 55.5\% of land use of Praya was for residential area. Agricultural area in Praya was about 13.3 \%, whilst the use land for office area in Praya was 9.4\% of land use of Praya.

Table 1. Land use change planning in Praya

\begin{tabular}{lcc}
\hline \multirow{2}{*}{\multicolumn{1}{c}{ Type of land use }} & \multicolumn{2}{c}{ Area (ha) } \\
\cline { 2 - 3 } & Existing & Land use planning in 2034 \\
\hline Industrial area & 1.2 & 1.5 \\
Garden & 0.6 & 0.0 \\
Health facilities & 0.8 & 0.8 \\
Empty land & 29.6 & 0.0 \\
Education area & 17.5 & 20.6 \\
Business district area & 11.1 & 43.8 \\
Religious facilities & 4.6 & 4.4 \\
Office area & 32.4 & 41.2 \\
Settlement area & 189.2 & 218.3 \\
Green space & 10.9 & 12.3 \\
Agricultural area & 45.8 & 0.6 \\
\hline
\end{tabular}

\subsection{Data analysis}

The data used in this research was in the form of tabular and spatial data that must be translated first into Geographic Information System (GIS) data format, in which each component of the data should have a spatial and attribute data so that the data could be processed using GIS approach with ArcGis 10.1 software. Based on the type of the area, Praya is classified as small city. Thus, it was recommended to use a 10-year return period for primary channel calculations (Suripin, 2004).

Design rainfall discharge is calculation step employing Rational Method using ArcGIS. It, firstly, calculated surface runoff using Rational Method $Q=0,00278 \mathrm{C}$ I A. This formula must be converted into GIS concept. Each component must have spatial and attribute data. The value of coefficient $C$ was then obtained from the change of land use planning in 2034 . Second, the results of surface runoff calculations using rational method could be described directly into flood planning map for several periods. Third, capacity of the channels and rainfall discharge were compared. To find out the capabilities of channel capacity against discharge plan, the difference between existing discharge and rainfall discharge plan should be calculated.

\section{Results and discussions}

\subsection{The analysis of design rainfall}

Design rainfall is the highest rainfall that may occur in an area with a certain chance. The purpose of design rainfall analysis is to obtain high rainfall with a certain return 
period. In this study, Gumbel and Log Pearson III methods were employed to analyze the design rainfall.

An example of average rainfall value and standard deviation value calculation is as follows. The calculation of design rainfall is presented in Equation 1.

$$
\bar{x}=\frac{1}{n} \sum_{i=1}^{n} x_{i}
$$

In this study, $n$ was 10 and sum of rainfall $\left(\sum x_{i}\right)$ was 760.40 . Hence, the average rainfall was equal to $76.04 \mathrm{~mm}$. Meanwhile, the calculation of standard deviation was done using Equation 2. The result of rainfall standard deviation calculation was 11.89.

$$
s_{x}=\sqrt{\frac{\sum_{i=1}^{n}\left(\bar{x}-x_{i}\right)^{2}}{n=1}}
$$

The results of the calculations of reduced variance $\left(Y_{t}\right)$, reduced mean $\left(Y_{n}\right)$, reduced standard $\left(S_{n}\right)$, frequency factor $(k)$, average rainfall $(R$; in $\mathrm{mm})$, and maximum daily rainfall $\left(R_{t}\right)$ plan using Gumbel method (in $\mathrm{mm}$ ) are presented in Appendix Table A. The calculation of $Y_{t}$ was used formula in Equation 3.

$$
R_{t}=R+\left(\frac{\sigma r}{S_{n}} \times\left(Y_{t}-Y_{n}\right)\right)
$$

Meanwhile, the calculation using Log Person III method is presented in Appendix Table B and $\mathrm{C}$.

\subsection{Suitable distribution test}

Suitable distribution test was intended to assess whether a distribution could be used or not for a series of available data. In this study, suitable distribution tests were done using two statistical methods, namely Chi-square test and Kolmogorov-Smirnov test.

\subsubsection{Chi-Square Test}

With the degrees of freedom (df) = 1 and level of significance $(\alpha)=5 \%$, the obtained value for $\chi^{2}$ in chi square table was 3.841. Calculation based on Chi-squared distribution on the results of Gumbel method obtained a value of 3.60. It could be inferred that the calculated $\chi^{2}$ value is smaller than $\chi^{2}$ value in the table or $3.60<3.841$. Thus, Gumbel distribution is acceptable to be used to calculate the design rainfall.

\subsubsection{Kolmogorov- Smirnov Test}

Calculation of Gumbel probability distribution with a significance level of 5\% and the amount of data (n) 10 retrieved $D_{\max }=0.2$ and $D_{0}=0.41$. Kolmogorov-Smirnov test shows that $\mathrm{D}_{\max }<\mathrm{D}_{\text {critical }}$ or $0.2<0.41$, so it can be inferred that the Gumbel distribution is acceptable.

Based on distribution tests against those two methods, Gumbel and Log Pearson III methods are equally viable to be used for next calculations. If viewed from the values of 
average rainfall resulted by both methods, Gumbel method has higher rainfall average than Log Pearson III method.

\subsection{Hydraulic analysis of drainage channels}

Hydraulic analysis aimed to analyze capacity of existing channels by calculating the slope, cross-section area, wet sections, hydraulic radian and the slope of uniform flow of water surface.

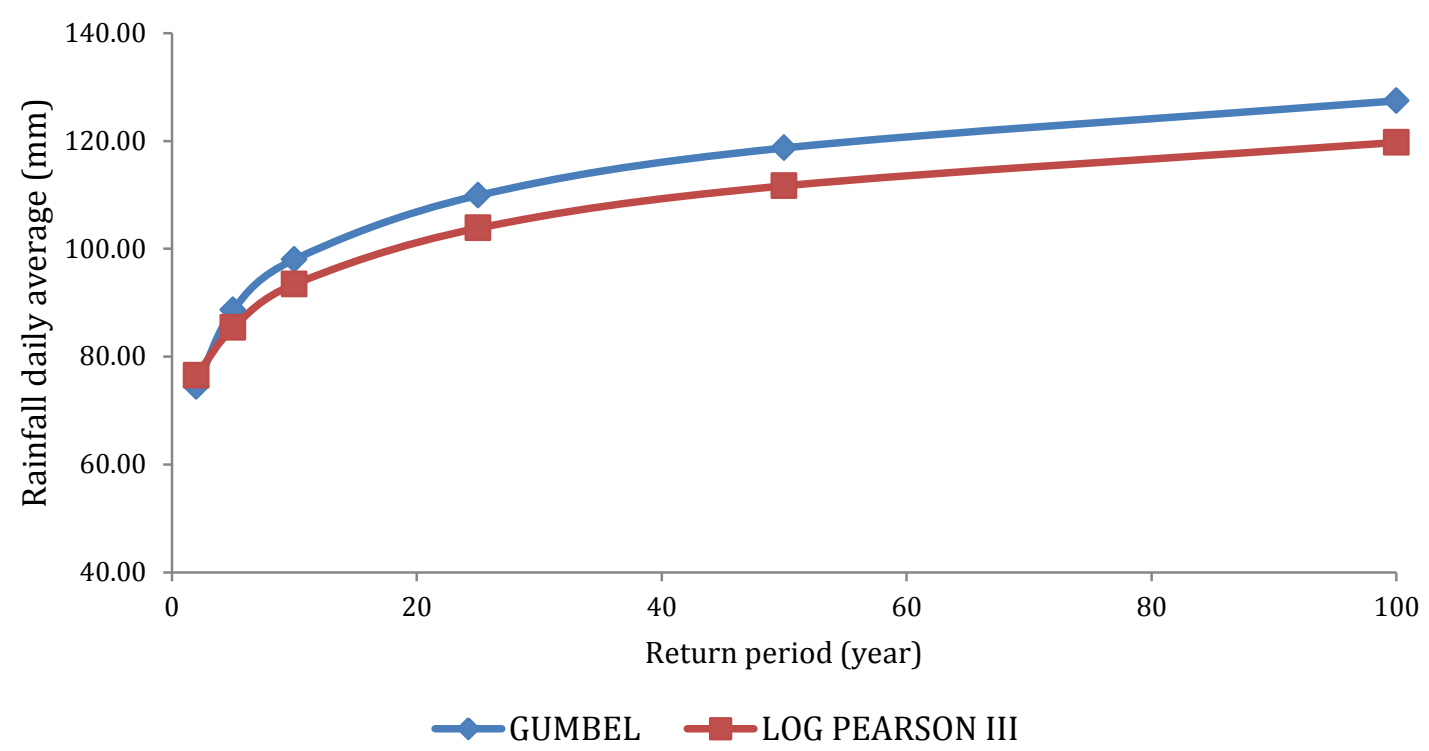

Figure 5. Chart showing comparison of average rainfall values calculated using Gumbel and Log Pearson III methods

An example of calculation of each component affecting the channel discharge will be presented in this paper. Primary Channel 8 segment 2 is presented in the Appendix.

In this study, the calculation results are as follows. Catchment area $(A)$ is equal to 10.4 hectares, run-off coefficient $(C)$ is equal to 0.6 , length of channel $(L)$ is equal to 318 meters, length of run-off $(L o)$ is equal to 126 meters, length of stream $(L s)$ is equal to 527 meters, flow velocity $(V)$ is equal to $0.9 \mathrm{~m} /$ second and the slope $(S)$ is equal to 0.0016 .

Inlet time $=t_{\mathrm{o}}=0,0195\left(\frac{L o}{\sqrt{S}}\right)^{0,77}$

$t_{o}=0,0195\left(\frac{126}{\sqrt{0,0016}}\right)^{0,77}=9,62$ minutes

Conduit time $=t_{d}=\frac{L}{60 v}=\frac{318}{60 \times 0,9}=10$ minutes 
Time of concentration $\left(t_{c}\right)=t_{0}+t_{d}$

$$
\begin{aligned}
& =9.62+10 \\
& =19.62 \text { minutes }
\end{aligned}
$$

\subsubsection{Rainfall intensity (I)}

Rainfall intensity is the height or depth of rainwater per unit of time. Rainfall intensity could be calculated using Mononobe formula. This formula is used when short term rain data is not available, but daily rainfall data is available. The calculation is as follows:

$$
I=\frac{R_{24}}{24}\left[\frac{24}{t c}\right]^{2 / 3}=\frac{98}{24}\left[\frac{24}{\left(\frac{19,62}{60}\right)}\right]^{2 / 3}=72.37 \mathrm{~mm} / \text { hour }
$$

Analysis of design rainfall discharge

The method used for calculation of rainfall discharge was rational method. Run-off coefficient of a catchment area was determined by averaging values of run-off coefficient in each type of land use which had been planned for the year of 2034. $C$ values were then inputted into GIS database and calculation process was conducted using rational formula which had been translated into shapefile data format in GIS software.

\section{The analysis of channel capacity}

The results of channel capacity analysis based on design rainfall discharge for the year of 2034 indicate 30, out of 52, channels which are incapable of accommodating rainfall discharge. Channel segments with insufficient capacity to hold rainwater should be handled by widening the dimension of the channels. The list of those channel segments is presented in Table D in the Appendix.

\subsection{Infiltration wells}

Infiltration well serves to accommodate and absorb flood discharge. According to SNI 03-2453-2002, general requirements that must be met in making infiltration well are as follows:

- Infiltration well must be placed on a relatively flat land,

- The water that goes into the infiltration well must not be polluted,

- Determination of infiltration well location should consider the safety of surrounding buildings,

- Infiltration well making should pay attention to government regulations, and

- If there are terms and conditions which could not be met, the making of infiltration well should be approved by authorized institutions first.

An example of infiltration well analysis of a flooding location at Hasanuddin Street is as follows:

The plan of infiltration well dimension, diameter $(D)=0.8 \mathrm{~m}$, depth $(H)=3 \mathrm{~m}$, permeability $(k)=12.6 \mathrm{~cm} /$ hour $=3.02 \mathrm{~m} /$ day, area $(A)=3.6841 \mathrm{ha}=36.841 \mathrm{~m}^{2}$, daily rainfall $=98 \mathrm{~mm}$, volume of flood $=29.473 \mathrm{~m}^{3}$, coefficient $(C)=0.7$, volume of flood 
occurrence $=2.034 \mathrm{~m}^{3}$, effective rainfall (te) $=1.02$ hour, well area $=8.04 \mathrm{~m}^{2}$, and volume of rainwater absorbed in the well $=1.03 \mathrm{~m} /$ day $/$ unit.

Total number of required well is

$$
\Sigma_{\text {wells }}=\frac{\text { Volume of flood }}{\text { Volume of flood occurrence }}=\frac{29.473}{2.034}=14 \text { well units }
$$

Based on the results of analysis on the application of infiltration well at some locations which were often inundated in Praya, it was obtained a total number of required wells as many as 179 units. The result is revealed in Figure 6.

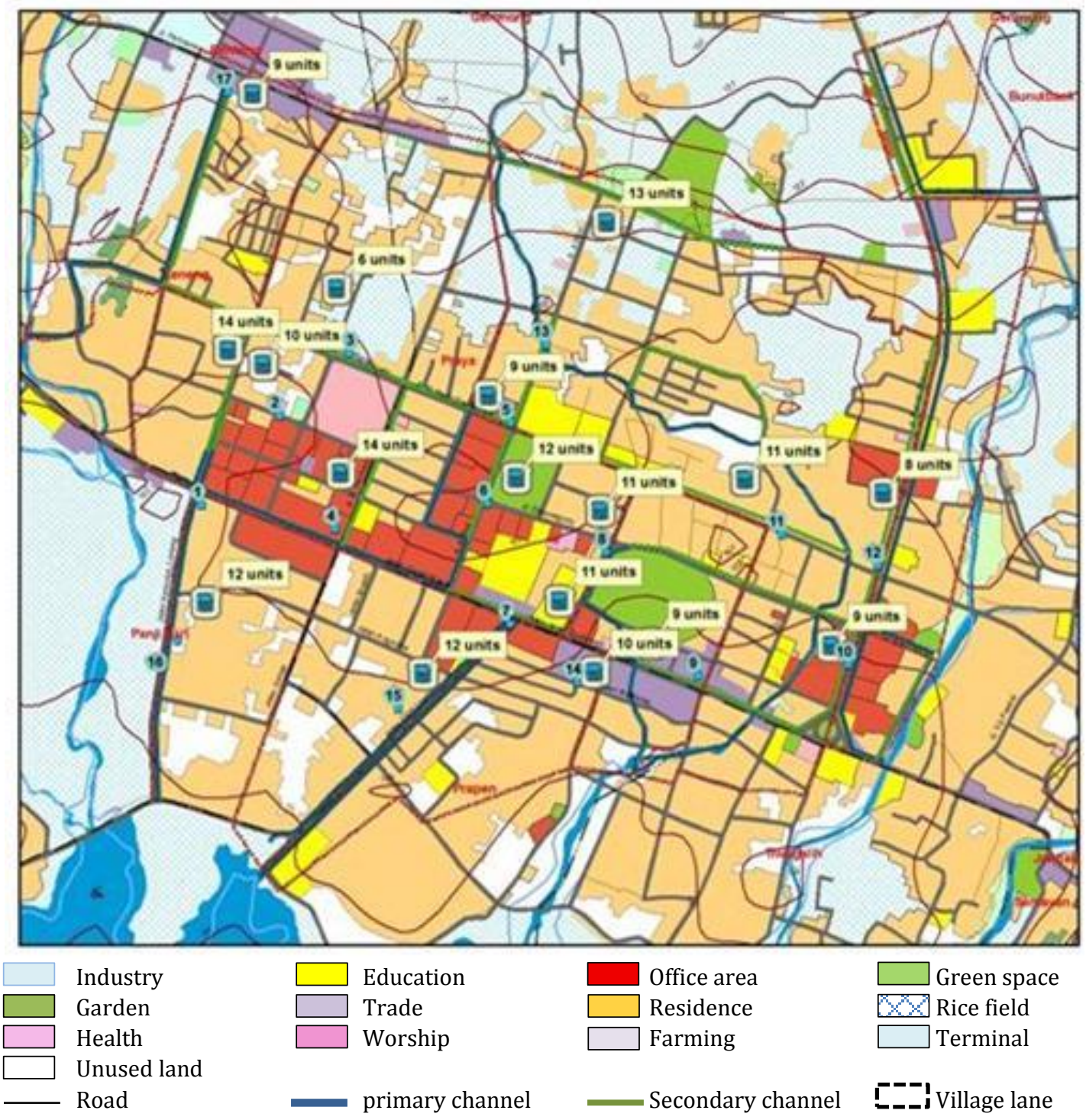

Figure 6. The locations of infiltration wells 


\section{Conclusion}

The value of the coefficient $C$ in the year of 2034 for each catchment area has increased due to changes in land use from agricultural area into settlement area. There are 30 segments of channel that is not capable of accommodating the design rainfall discharge in 2034. The type of channel that is handled by widening the dimension of channel and channel optimization is the one that is not capable of accommodating the design rainfall discharge. Additional channels with a total length of 3.191 meters are needed to be built in order to support that type of channel. Another solution is by making infiltration wells in inundation-prone area. Based on the plan in 2034, as many as 179 units of infiltration well are required to solve the inundation problem.

\section{References}

Betaubun, R., Suseno, D. H., \& Ussyandawayanty. (2012). Analisis Penanggulangan Genangan di Kota Ambon Pada DAS Waitomu Kelurahan Uritetu. Jurnal Teknologi, 9(2), 1087-1096.

BPS. (2017a). Kabupaten Lombok Tengah dalam Angka 2017. Lombok Tengah: Badan Pusat Statistik Kabupaten Lombok Tengah.

BPS. (2017b). Penduduk Kabupaten Lombok Tengah, 2011-2015. Retrieved from https://lomboktengahkab.bps.go.id/dynamictable/2017/01/18/35/pendudukkabupaten-lombok-tengah-2011-2015.html

Brooks, K., Ftolliot, P., \& Magner, J. (2013). Hydrology and The Management of Watersheds Fourth Edition. Iowa: John Wiley \& Sons, Inc.

Button, K., Elisabeth, Jeyaraj, Muniz, E., \& Ma, R. (2010). Adapting Sustainable Urban Drainage Systems to Stormwater Management in an Informal Setting.

Fengxiang, Q., Wanyan, Y., \& Li, Q. (2018). Influencing Factors and Strategies for Sustainable Urban Drainage System. Civil Engineering Research Journal, 3(4), 1-3. http://doi.org/10.19080/CERJ.2018.03.555616

Freevert, R., Schwab, G., Edminster, T., \& Barnes, K. (1963). Soil and Water Conservation Engineering. New York: John Willey \& Sons, Inc.

Hasmar, H. (2012). Drainase Terapan. Yogyakarta: UII Press.

Jifa, A. N., Rachmansyah, A., \& Afandhi, A. (2018). Analysis of Infiltration Well Dimensional in Kedungkandang District, Malang City , Indonesia. J-PAL, 9(1), 33-38.

Koordinator Statistik Kecamatan Praya. (2017). Kecamatan Praya dalam Angka 2017. Praya: Badan Pusat Statistik Kabupaten Lombok Tengah.

Kusumadewi, D. A., Djakfar, L., \& Bisri, M. (2012). Arahan S spasial teknologi drainase untuk mereduksi genangan di sub daerah aliran Sungai Watu bagian hilir. Jurnal Teknik Pengairan, 3(2), 258-276.

Sunjoto, S. (1994). Infiltration well and urban drainage concept. Future Groundwater Resources at Risk, (222), 527-532.

Suripin. (2004). Sustainable Urban Drainage System. Yogyakarta: Andi Offset. 


\section{Appendix}

Table A. The results of maximum daily rainfall

\begin{tabular}{cccccccc}
\hline PUH $(T)$ & $R$ & $\Sigma r$ & $S n$ & $Y t$ & $Y n$ & \multicolumn{1}{c}{$Y n$} & \multicolumn{1}{c}{$k$} \\
\hline 2 & 76.04 & 11.89 & 0.9496 & 0.3665 & 0.4952 & 74.43 & -0.14 \\
5 & 76.04 & 11.89 & 0.9496 & 1.4999 & 0.4952 & 88.62 & 1.06 \\
10 & 76.04 & 11.89 & 0.9496 & 2.2502 & 0.4952 & 98.02 & 1.85 \\
25 & 76.04 & 11.89 & 0.9496 & 3.1985 & 0.4952 & 109.89 & 2.85 \\
50 & 76.04 & 11.89 & 0.9496 & 3.9019 & 0.4952 & 118.70 & 3.59 \\
100 & 76.04 & 11.89 & 0.9496 & 4.6001 & 0.4952 & 127.44 & 4.32 \\
\hline
\end{tabular}

Table B. The results of calculation using Log Pearson III method

\begin{tabular}{rrrrcr}
\hline Year & \multicolumn{1}{c}{$x_{i}(\mathrm{~mm})$} & \multicolumn{1}{c}{$p(\%)$} & \multicolumn{1}{c}{$\log x_{i}$} & $\left(\log x_{i}-\log x\right)^{2}$ & $\left(\log x_{i}-\log x\right)^{3}$ \\
\hline 2006 & 54,30 & 9.0909 & 1.73 & -0.14 & -0.002816 \\
2011 & 63.20 & 18.1818 & 1.80 & -0.08 & -0.000427 \\
2007 & 68.43 & 27.2727 & 1.84 & -0.04 & -0.000068 \\
2009 & 75.07 & 36.3636 & 1.88 & 0.00 & 0.000000 \\
2013 & 76.40 & 45.4545 & 1.88 & 0.01 & 0.000000 \\
2012 & 78.33 & 54.5455 & 1.89 & 0.02 & 0.000006 \\
2010 & 80.00 & 63.6364 & 1.90 & 0.03 & 0.000020 \\
2008 & 82.37 & 72.7273 & 1.92 & 0.04 & 0.000063 \\
2014 & 85.73 & 81.8182 & 1.93 & 0.06 & 0.000187 \\
2015 & 96.57 & 90.9091 & 1.98 & 0.11 & 0.001289 \\
\hline & 760.40 & & 18.76 & & -0.001746 \\
& 76.04 & & 1.88 & & \\
& 11.89 & & 0.07 & & \\
& & -0.7 & & \\
\hline
\end{tabular}

Table C. The results of design rainfall calculation using Log Pearson III method

\begin{tabular}{cccccccc}
\hline \multirow{2}{*}{$\begin{array}{c}\text { Return } \\
\text { period }\end{array}$} & $\begin{array}{c}\text { Average } \\
(\text { Log) }\end{array}$ & $\begin{array}{c}\text { Seviation } \\
(\log )\end{array}$ & $\begin{array}{c}\text { Skewness } \\
(\text { Cs })\end{array}$ & $\begin{array}{c}\text { Probabilty } \\
(\%)\end{array}$ & $k$ & \multicolumn{2}{c}{ Design rainfall } \\
\hline 1.01 & 1.88 & 0.07 & -0.7 & 99 & -2.824 & 1.68 & 47.44 \\
2 & 1.88 & 0.07 & -0.7 & 50 & 0.116 & 1.88 & 76.60 \\
5 & 1.88 & 0.07 & -0.7 & 20 & 0.857 & 1.94 & 86.43 \\
10 & 1.88 & 0.07 & -0.7 & 10 & 1.183 & 1.96 & 91.14 \\
25 & 1.88 & 0.07 & -0.7 & 4 & 1.488 & 1.98 & 95.78 \\
50 & 1.88 & 0.07 & -0.7 & 2 & 1.663 & 1.99 & 98.56 \\
100 & 1.88 & 0.07 & -0.7 & 1 & 1.806 & 2.00 & 100.88 \\
1000 & 1.88 & 0.07 & -0.7 & 0.1 & 2.140 & 2.03 & 106.52 \\
\hline
\end{tabular}




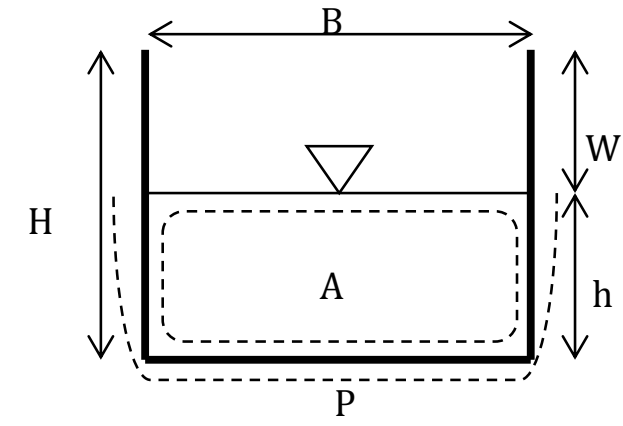

$$
\begin{aligned}
& A=B \times h \\
& P=B+2 h \\
& =1 \times 0.8 \\
& =1,0+2 \times 0.8 \\
& R=\frac{A}{P}=\frac{0.8}{2.6}=0.3 \mathrm{~m} \\
& =0.8 \mathrm{~m}^{2} \\
& =2.6 \mathrm{~m}
\end{aligned}
$$

$$
S=\left(\frac{v \times n}{R^{\frac{2}{3}}}\right)^{2}=\left(\frac{0.87 \times 0.02}{0.41^{\frac{2}{3}}}\right)^{2}=0.0015
$$

Channel Discharge $(Q) \quad=A \times V$

$$
\begin{aligned}
& =0.8 \mathrm{~m}^{2} \times 0.87 \mathrm{~m} / \mathrm{sec} \\
& =0.69 \mathrm{~m}^{3} / \mathrm{sec}
\end{aligned}
$$

Time of concentration $\left(t_{c}\right)=$ inlet time $\left(t_{o}\right)+$ conduit time $\left(t_{d}\right)$ 
Table D. List of channel segments with insufficient capacity in holding rainwater

\begin{tabular}{|c|c|c|c|c|c|c|}
\hline Channel segment & Type & $\begin{array}{c}\mathrm{V} \\
(\mathrm{m} / \mathrm{sec})\end{array}$ & $\begin{array}{c}A \\
\left(\mathrm{~m}^{2}\right)\end{array}$ & $\begin{array}{l}\text { Capacity } \\
\left(\mathrm{m}^{3} / \mathrm{sec}\right)\end{array}$ & $\begin{array}{c}\text { Qacc } \\
\left(\mathrm{m}^{3} / \mathrm{sec}\right)\end{array}$ & Description \\
\hline P1.2 & Primary & 0.8 & 0.4 & 0.3 & 1.0 & overflow \\
\hline P2.1 & Primary & 0.9 & 1.2 & 1.1 & 1.3 & overflow \\
\hline P2.2 & Primary & 1.0 & 1.2 & 1.2 & 1.3 & overflow \\
\hline $\mathrm{S} 4.2$ & Secondary & 0.8 & 0.3 & 0.3 & 0.8 & overflow \\
\hline S4.4 & Secondary & 0.9 & 0.3 & 0.3 & 0.4 & overflow \\
\hline S4.3 & Secondary & 1.0 & 0.3 & 0.3 & 1.2 & overflow \\
\hline $\mathrm{S} 4.5$ & Secondary & 1.0 & 0.5 & 0.5 & 0.8 & overflow \\
\hline P5.2 & Primary & 0.8 & 1.7 & 1.4 & 2.5 & overflow \\
\hline S6.1 & Secondary & 1.0 & 0.8 & 0.8 & 1.7 & overflow \\
\hline P6.2 & Primary & 1.0 & 1.4 & 1.4 & 2.4 & overflow \\
\hline P6.3 & Primary & 1.6 & 1.4 & 2.2 & 4.5 & overflow \\
\hline P6.4 & Primary & 1.6 & 1.8 & 2.8 & 4.4 & overflow \\
\hline S7.1 & Secondary & 1.3 & 0.6 & 0.7 & 1.0 & overflow \\
\hline S7.2 & Secondary & 0.3 & 0.5 & 0.2 & 0.3 & overflow \\
\hline P7.3 & Primary & 1.6 & 1.8 & 2.8 & 3.5 & overflow \\
\hline S8.1 & Secondary & 0.6 & 0.2 & 0.2 & 0.3 & overflow \\
\hline P8.1 & Primary & 0.9 & 0.8 & 0.7 & 1.3 & overflow \\
\hline S8.2 & Secondary & 1.0 & 0.2 & 0.2 & 0.4 & overflow \\
\hline P8.2 & Primary & 0.9 & 0.8 & 0.7 & 2.9 & overflow \\
\hline P8.3 & Primary & 1.1 & 0.8 & 0.9 & 3.5 & overflow \\
\hline S9.1 & Secondary & 0.8 & 0.3 & 0.2 & 0.3 & overflow \\
\hline P9.1 & Primary & 1.3 & 1.0 & 1.2 & 1.3 & overflow \\
\hline S9.2 & Secondary & 0.4 & 0.2 & 0.1 & 0.2 & overflow \\
\hline P9.2 & Primary & 1.4 & 1.0 & 1.3 & 2.3 & overflow \\
\hline S9.3 & Secondary & 0.5 & 0.2 & 0.1 & 0.2 & overflow \\
\hline S10.1 & Secondary & 1.0 & 0.4 & 0.4 & 0.4 & overflow \\
\hline P10.1 & Primary & 1.2 & 1.0 & 1.2 & 1.4 & overflow \\
\hline $\mathrm{S} 10.2$ & Secondary & 0.5 & 0.2 & 0.1 & 0.2 & overflow \\
\hline P10.2 & Primary & 1.4 & 1.0 & 1.3 & 2.7 & overflow \\
\hline P10.3 & Primary & 1.6 & 1.0 & 1.5 & 4.0 & overflow \\
\hline
\end{tabular}

